\title{
STUDY OF DURABILITY OF ALABASTER USED IN THE TEMPLES OF LUXOR AND KARNAK AND LABORATORY EVALUATION OF CONSOLIDATION TREATMENT
}

\author{
Abd El-Tawab, N. ${ }^{1} \&$ Askalany, M. ${ }^{2}$ \\ ${ }^{I}$ Conservation dep., Faculty of Archaeology, South Valley Univ., Qena, Egypt \\ , ${ }^{2}$ Geology Dep., Faculty of Science South Valley_Univ., Qena, Egypt - e-mail: drnabil_bader@yahoo.com
}

\begin{abstract}
Alabaster is an ornamental stone that was widely used in ancient Egypt and it had a lot of deterioration factors. The present paper deals with two types of alabaster that located at Wadi Sannur and Wadi El Assuity, and their durability and geotechnical characteristics. These characteristics were examined before and after artificial ageing using simple analytical methods. Physical and mechanical properties were carried out on samples from quarries providing each type and the same samples were then exposed to artificial ageing with sodium chloride and heat which effectively produced deterioration comparable with that in Luxor and Karnak temples. The results were tested on different alabaster objects from Luxor and Karnak temples where the use of alabaster. The study was also aimed to evaluate the efficiency of the various commercial silane-based and acrylic products in laboratory in order to recommend the protective treatment for the conservative treatment of the alabaster. To fulfill this goal a soaking characterization and accelerated ageing tests were performed. Quite satisfying results have been observed, except for the original color of the alabaster samples and for particular condition of application.
\end{abstract}

Keywords: Alabaster, Wadi Sannur, Wadi Assiuty, Ageing, Consolidant

\section{Introduction}

Alabaster name may derive further from the Ancient Egyptian word alabaste, which refers to vessels of the Egyptian goddess Bast, who was represented as a lioness and frequently depicted as such when placed atop these alabaster vessels. It has been suggested that the name was derived from the town of Alabaster on in Egypt, while an arabic etymological origin has also been suggested by Harrell, 1990 [1]. Travertine also is commonly referred to as alabaster in the Egyptological literature, with this term being derived from alabastrites, the ancient Roman name for the stone [2]. The technically correct name for the Egyptian stone is "travertine" and its dense, non-porous character classifies it as the sub-variety "calcareous sinter". It is very different from the spongy-looking, highly porous "calcareous tufa" from near Tivoli, Italy, which is more closely associated with the name "travertine" in the minds of many archaeologists and art historians. Egyptian travertine is also referred to by some scholars as Egyptian or Oriental (as opposed to true) alabaster, "calcitealabaster" or simply "calcite" [3]. In ancient Egypt alabaster is one of the stone most employed in subsidiary building 
materials, also one of the main status symbols as presents of the pharaohs to the gods or to other king, It was popular in ancient Egypt for funerary vessels to contain the viscera of mummies and with the Etruscans for vases, urns, and ornaments. In early dynastic times the Egyptians used alabaster as a subsidiary building material for lining passages and rooms. It was employed mainly for small objects such as statuettes and shawabti figures, canopic and unguent jars, vases of many forms, bowls and dishes, offering tables and paving stones. Larger objects were also occasionally carved from alabaster, including life-size and colossal statues, sarcophagi, embalming beds and shrines. By the Middle Kingdom alabaster was quarried at Hatnub and used to carve colossal statues. In the New Kingdom alabaster objects were widely employed [4].The Egyptians used alabaster particularly for column, pilasters, socles, portals, household items, ritual objects, and for a number of different funerary purposes such as canopic equipment, etc. However, after the end of the pharaonic period, little mention is made of alabaster until the time of Mohamed Ali Basha, who used it to adorn his mosque at the Citadel of Salah El Din. There are nine known ancient quarries for alabaster, all in Middle Egypt. Comprehensive treatments of these quarries are given by Aston, et al. [5].The most famous alabaster quarries in Egypt are located at Hatnub, although smaller sources between Helwan and Asyut were exploited in Pharaonic times. Three of the ancient quarries are in fissure-fill deposits (Wadi Gerrawi, Wadi Araba and ElQawatir), with the rest excavated in cavern-fill alabaster, the alabaster of this quarries were used in the sphinx of an unknown Eighteenth or Nineteenth Dynasty (New Kingdom) king at Memphis, and the two alabaster barque shrines for the Eighteenth Dynasty Kings Amenhotep I/Thutmose I and Thutmose IV in the Open Air Museum at Luxor's Karnak Temple [6]. The aim of the present study is to define the characteristics of Egyptian alabaster with the emphasis to the alabaster durability and its geotechnical properties and measuring of the deterioration and suitable consolidation products for the deteriorated alabaster.

\section{The Geology of the studied Alabaster 2.1. Wadi Sannur alabaster}

Wadi Sannur site was identified by as an important building stone source for interior and exterior walls veneered at Mohamed Ali Mosque in Cairo's Citadel fortress which was built between 1830 and 1857 [7]. Wadi Sannur, that Egypt's bestdeveloped limestone cavern was recently discovered. It is partially filled with stalactites, stalagmites, fig. (1-a, b) [8]. Geographically it lies at $70 \mathrm{~km}$ south-east of Beni suef. It has approximately 13 quarries of alabaster, [9]. Using uranium/thorium radiometric dating estimate the maximum possible age of the alabaster speleothems in the Wadi Sannur cavern at 200000 years, and suggest that these were probably deposited during the pluvial, or wet climatic stages of the latest Quaternary [10]. Whether this is true generally for Egypt's alabaster deposits is unknown, but they must, at least, post-date the early Pliocene (and last) marine transgression in the region about 5 million years ago [11]. Egyptian alabaster in Wadi Sannur was deposited from hydrothermal solutions. The source of the heat was probably increased crustal heat flow associated with Red Sea rifting. Based on stable oxygen isotopic values $\left(\begin{array}{lll}\delta & \mathrm{O}\end{array}\right)$ [12] estimated the water temperature for the Wadi Araba and Wadi Sannur alabaster to be between $32^{\circ} \mathrm{C}$ and $86^{\circ} \mathrm{C}$. Color banding in Egyptian alabaster paralleled the active precipitation surfaces within the subterranean cavities and marked periodic changes in the physicochemical environment. This stone typically consists of thin bands of milky to creamy white, opaque calcite alternating with thicker bands of brownish (often 
tinted with orange or especially yellow), translucent calcite, fig. (2-a, b, c). 'Amber' and 'honey' are two particularly apt terms often used to describe the color of the
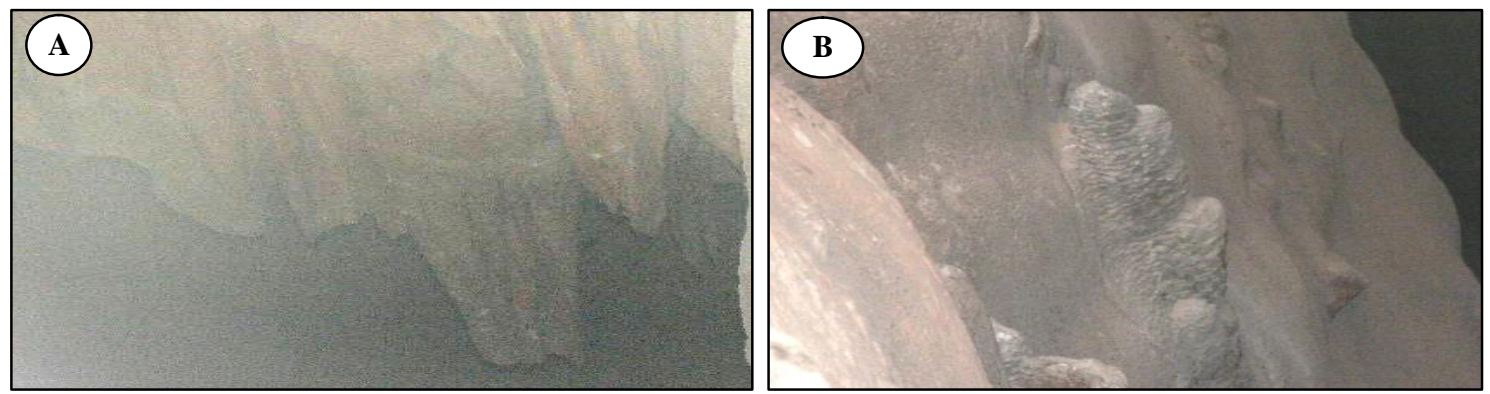

Figure $1(\mathrm{a}, \mathrm{b})$ alabaster stone in Wadi Sannur, $\underline{\mathbf{a}}$ Stalactites, $\underline{\mathbf{b}}$ stalagmites
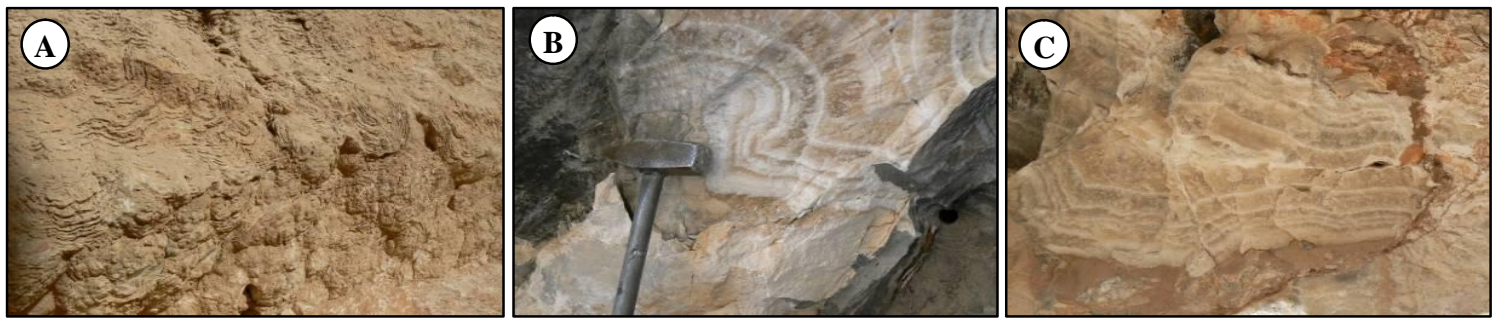

Figure $2(a, b, c)$ the colloform structure of alabaster in Wadi Sannur and thin bands of milky to creamy white, opaque calcite alternating with thicker bands of brownish.

\subsection{Wadi El Assiuty alabaster}

Its occur between distinctive hills chain with height approximately $75 \mathrm{~m}$, which adjacency this wide extension of wadi Assiuty from left side [13].The quarry takes place at old narrow roadside to connect between desert and agriculture area which was possibly preparation at Mohamed Ali pasha rule. The alabaster quarries of wadi Assiuty occur at downhill eastern slope for lime hill at arise $60 \mathrm{~m}$ from bottom of valley. The obvious mass which may looking from that quarry reached approximately 74 lengths, $20 \mathrm{~m}$ width, and 20 highest. This quarry unemployed now and it is enter nature reserve zone [7]. It is observed that the

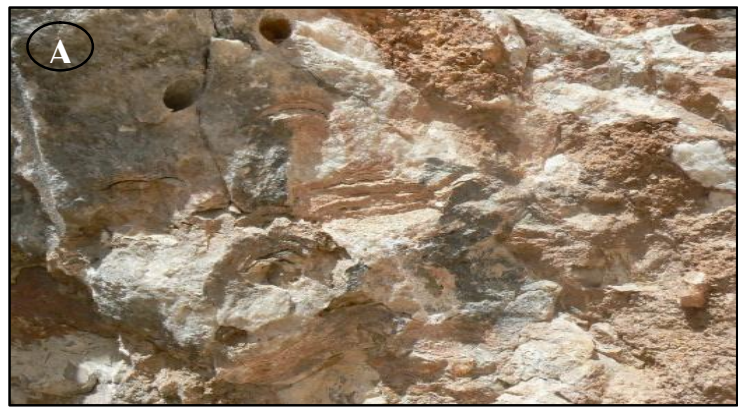

Egyptian alabaster is translucent brownish and opaque whitish bands consist of fibrous aggregates of straight to mainly curved, elongated calcite crystals (mostly less than $5 \mathrm{~mm}$ in length) that are oriented approximately perpendicular to the color banding. It is saccharoidal milky white and contains affluent tiny cavities stained with red iron oxide, fig. (.3-a, b). Patches of non-fibrous, irregular to equant calcite crystals also occasionally occur. The principal petrographic difference between the color bands is that the whitish calcite has abundant fluid inclusions (mostly less than $5 \mu \mathrm{m}$ across), whereas these are nearly absent in the brownish calcite.

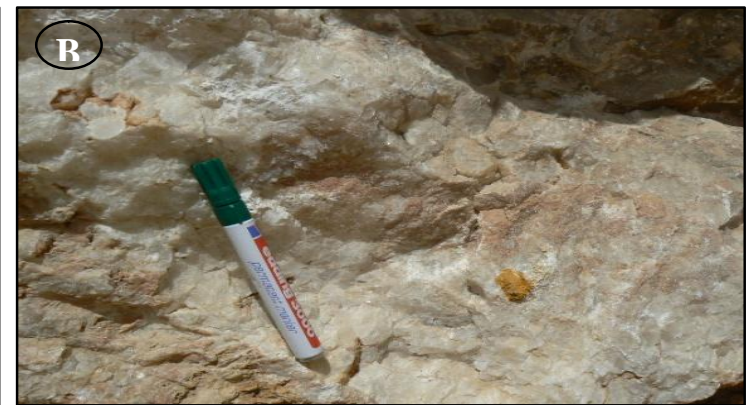

Figure $3(\mathrm{a}, \mathrm{b})$ massive alabaster from the Wadi Asyut, contains affluent tiny cavities stained with red iron oxide. 


\section{Deterioration of alabaster in Upper Egypt}

The deterioration of stone materials is a complex process caused by the interaction between numerous correlated factors: climatic region, urban pollution and properties of the material, leading to the chemical, physical/ mechanical and biological weathering. The main external influences on weathering in the site of alabaster on Luxor, Karnak temples and Luxor museum are daily and annual temperature variation. The recording showed isolated air temperatures ranging up to $53{ }^{\circ} \mathrm{C}$ during the summer months. Air temperatures $40{ }^{\circ} \mathrm{C}$ are common during the whole year, and hauls down to about $20{ }^{\circ} \mathrm{C}$ during nights during the same months and varies from less than 5 ${ }^{\circ} \mathrm{C}$ during winter nights with the exception of November to February rain occasional thundershowers. The result of this cycles of expansion and shrinkage in turn producing stress, strains on the alabaster minerals. Condensation, ground moisture, salt accumulations, wind and storms, all these impact results in physical, chemical and biological processes which affect the alabaster statues and artifacts [14]. The weathering of alabaster appears to be rather different from the weathering of other stone materials because of its chemical composition and its high porous texture. Freshly quarried and carved travertine is a beautiful, brightly colored stone. After prolonged exposure to sunlight, however, the brownish portions begin to fade and eventually are bleached to white. Any alabaster artifact left outdoors will suffer the same fate. The exterior surfaces of the chapel of Thutmose IV, offering table and barque shrines for kings Amenhotep I/Thutmose I at the Karnak and the statue of Amonite at Luxor, fig. (4-a, b, c), which exposure to sunlight for long time suffering from this phenomena. The bleaching is caused by sunlight ultraviolet, which deactivates the color centers in the calcite [3]. The alabaster monuments at Karnak and Luxor temples suffer from fracture and loss some architectural elements, fig. (5-a, b, c). Alabaster is far too soft for external use, it is hopelessly vulnerable to the elements, and it is too weak for building. It is so soft that it can be cut with a penknife, making it a ready target for vandals over the ages. Weathering of alabaster is accompanied by the formation of microcracks in the interior, primary in the boundaries between the mineral grains, fig. $(6-a, b, c)$. Microcracks as a result of mechanical stresses which may originate from mechanical loads, from of variation in temperature and humidity, from aggressive environment which can be acid residue from rainfall and product from a calcite reaction [15]. Alabaster decay represented characteristic in numerous pitting and cavities, fig. (7-a, b, c).

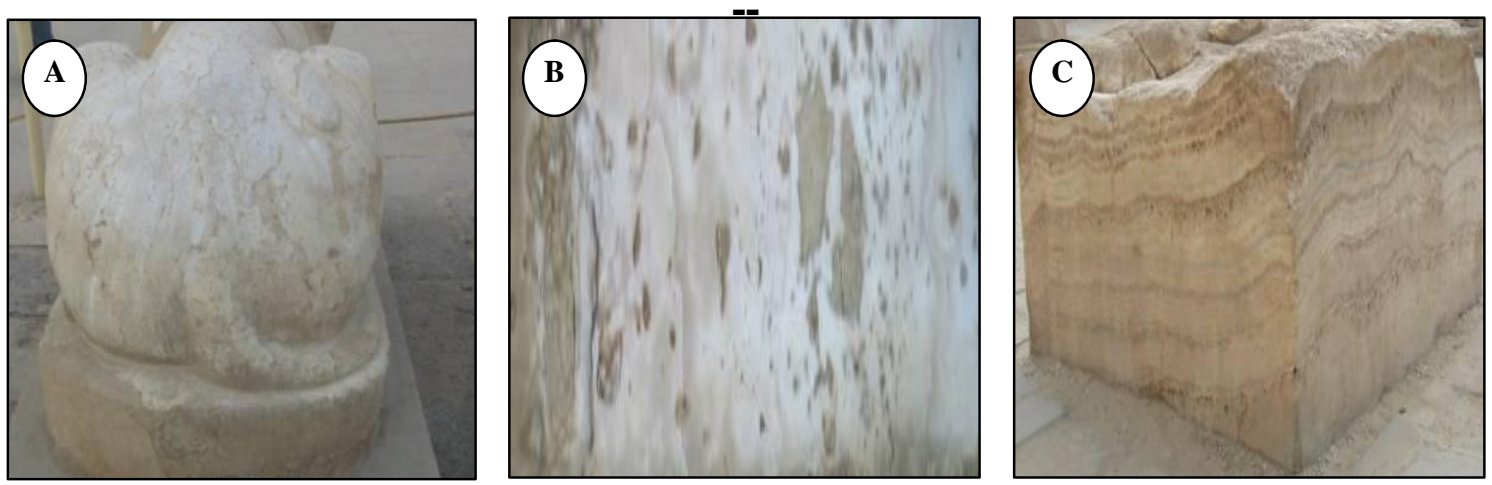

Figure $4(\mathrm{a}, \mathrm{b}, \mathrm{c})$ Alabaster monuments at Karnak temple showing the effects of bleaching by sunlight 

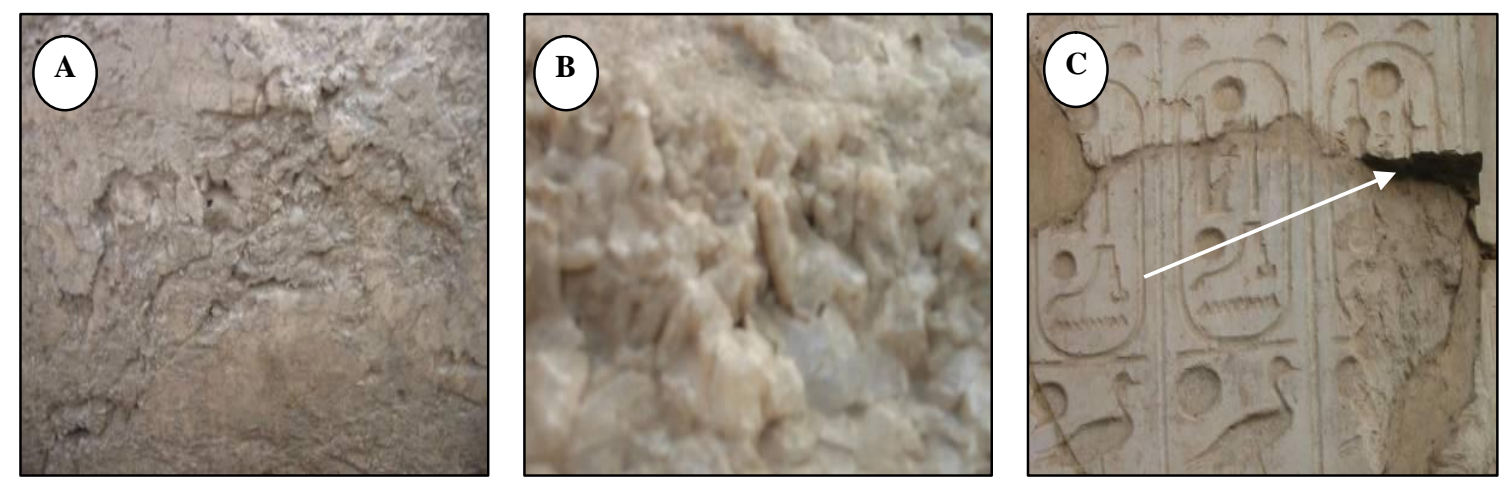

Figure $5(a, b, c)$ the Granular disintegration on the surface of alabaster offering table at Karnak temples and fracture and loss some architectural elements of alabaster monuments at Luxor.
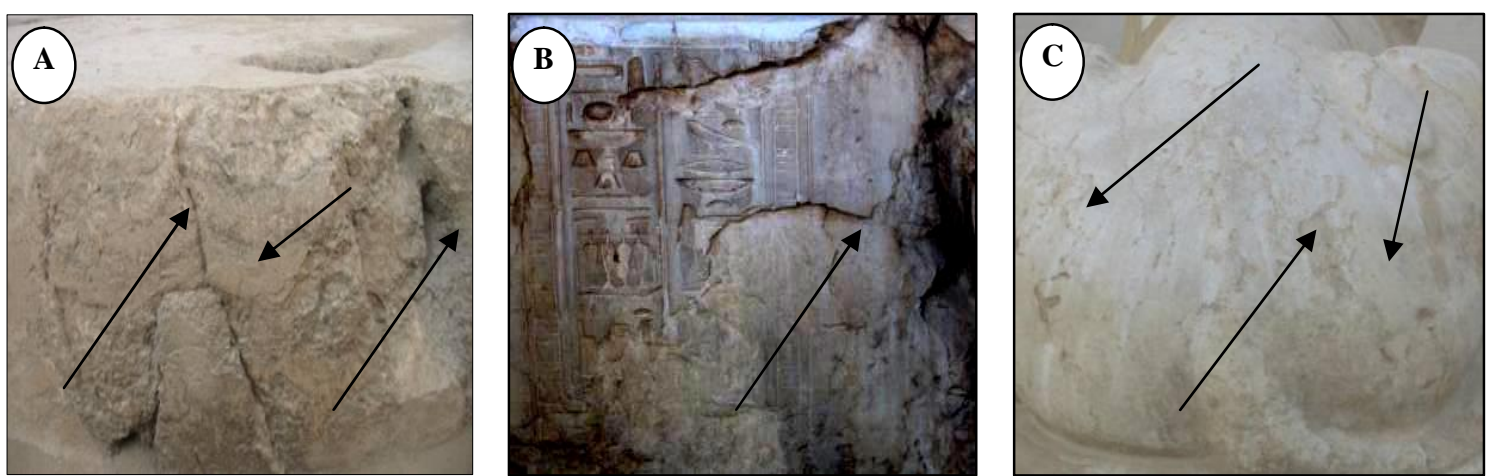

Figure $6(\mathrm{a}, \mathrm{b}, \mathrm{c})$ the cracks and microcracks and fissuring at the alabaster monuments at Luxor and Karnak temples.
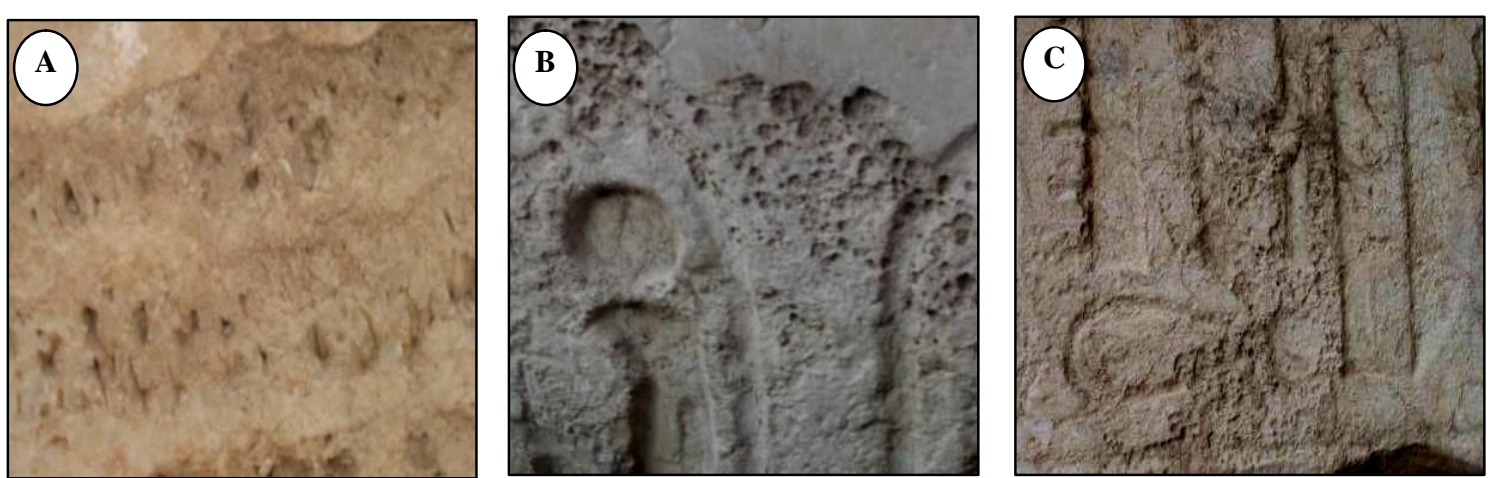

Figure $7(\mathrm{a}, \mathrm{b}, \mathrm{c})$ the different pitting and cavities in the alabaster monuments at Luxor and Karnak temples.

The reasons of this deformation are the rainwater, which is always slightly, because air contents carbon dioxide that is dissolved in water forming carbonic acid. Under such condition, carbonates of calcium may be transformed into bicarbonate and slowly dissolved and made this pitting and cavities. Also this acid water loaded with carbonic and sulfuric acid penetrates cracks and fissures and drips down surface of the alabaster. Calcite undergoes dissolution process when the PH level of water dripping on its surface or its porous systems below7.8. These dissolution processes are more noticeable for small-grain minerals (micrite) than for larger-grained stones (sparite). This affects a deferential dissolution that causes the statue ornamentation to lose definition. Also the carving of alabaster results in the opening of innumerable chiseling microfissures conductive to water intake. Water absorbed increases its volume with temperature variation. The transformation of calcite into gypsum by sulfuric acid 
(sulfation) induces an increase in volume of $83.24 \%$ that adulterates the superficial morphology and leads to the appearance of blisters. Most spectacular examples for proceeded weathering are completely destroyed offering table at Karnak temple. The final stage of this weathering is frequently characterized by disintegration of the alabaster; the cohesion between the grains is completely lost. The reasons of the observed deformation dramatically for repeated heating may lead to permanent dilatations due to microfracturing. Variation in moisture contents may be responsible for the deformation. Water is one of the main factors of decay of alabaster stone which one of the porous stone at Karnak and Luxor temples, as it plays a crucial role in almost every decay process, water penetrate into the pores of the stone by many ways as capillary suction from the soil or by condensation from the atmosphere. Thus water carries into the stone soluble salts which can crystallize in correspondence of the evaporation surface owing to the solution supersaturation. This process is the main cause of the efflorescence and subefflorescence formation. Halite and gypsum are the common salts at the alabaster stone in Upper Egypt. Halite and Gypsum are hygroscopic salt mixture mainly of sodium, magnesium, calcium, and chlorine ions. All these salts accumulation in the alabaster stone go along with local damage such as fissuration, spalling and flaking [16]. Water is also able to dissolve some of the stone's components. This phenomenon appeasers particular sever for calcareous stones like alabaster. Although alabaster has a very simple mineralogical composition, the mechanical weathering of alabaster due to its extremely anisotropic physical properties seems to be essential. The rock fabric, which includes grain size, grain aspects ratio, grain shape preferred orientation (texture) and the microcracks population, controls the materials behavior [17]. Biodeterioration add more deterioration aspects in the alabaster stone used in the temples in Upper Egypt. Microorganisms found growing on damaged alabaster surfaces. Biodeterioration problems arise and play the role of the degradation of alabaster by the growth of microorganisms between calcite grains and the aesthetic or visual effects of biodeterioration resulting from the growth of biological populations on alabaster surfaces alters their appearance due to chromatic alterations and development of biological patinas, fig. (8-a, b) [18]. Decomposition of calcite grains due to the effect of organic acid produced by these microorganisms, which changed into calcium sulphate when attacked by sulphuric acid that produced by the microorganisms, [19]. In the case of the certain object the behavior of the construction materials under weathering conditions is also predicted by the object's design, constructive elements and adjacent materials used, such cases as use of inappropriate jointing material, iron elements as iron oxidizes and becomes hydroxide, it increase its volume, then cracking and fissuring occur, fig (.9).
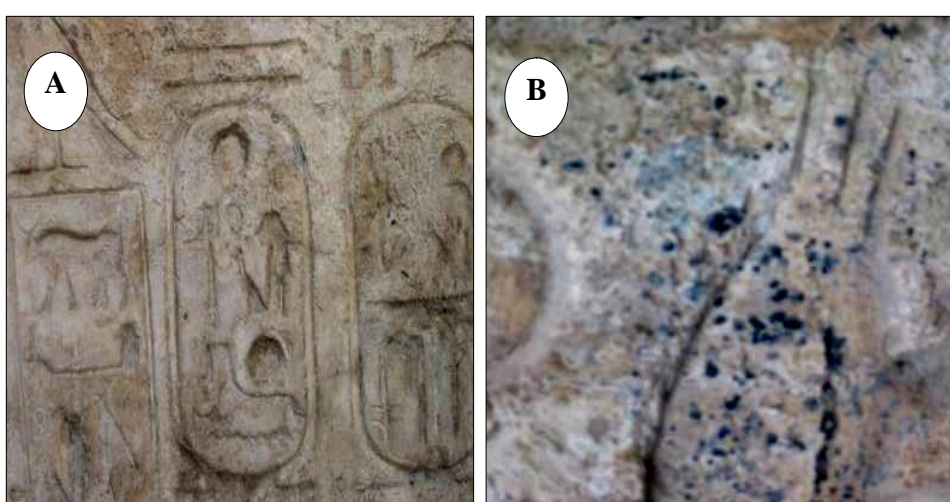

Figure $8(\mathrm{a}, \mathrm{b})$ the biodeterioration weathering at alabaster monuments.

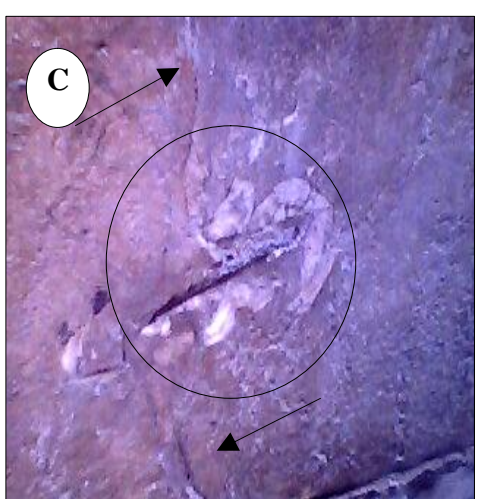

Figure (9) fault restoration using iron bars to tie the cracks. 


\section{Methods of study}

The laboratory study has tow division; the first one is for examining the characteristics of studied alabaster and the weathering process acting on alabaster used in Luxor and Karnak temples. The second division in this work is to examine and evaluate four co-polymer resins selected as stone surface consolidating for the weathered alabaster. Various alabaster samples have been collected from Wadi Sannur quarry and Wadi Assiuty quarry. Archaeological samples were taken from the statues and alabaster monuments in Luxor and Karnak temples. These samples were studied by Polarizing microscope, Thin sections were prepared from the studied samples, then Petrographical examination and photography was carried out under the polarizing microscope. Mineralogical composition, pore structure and percentage were characterized. Scanning electron microscopy (SEM JEOL JSM 6400) coupled with energy dispersive microanalysis (EDS) and the geochemical analysis of the samples consisted of XRF analysis. XRF measurements were performed in situ nondestructive analysis. XRF spectrometer for elemental analysis (JSX-3222), equipped with end window type X-ray tube, tube voltage 5 to $50 \mathrm{Kv}$ (in $1 \mathrm{Kv}$ steps), tube current 0.01 to $1.0 \mathrm{~mA}$, using $\mathrm{Rh}$ anode as target, window $\mathrm{Be}$, $127 \mu \mathrm{m}$ thick. X-ray fluorescence was detected by an $X$ Flash silicon drift detector with high speed electronics with an energy resolution $149 \mathrm{eV}$ at $\mathrm{Fe} \mathrm{K} \alpha$ spectral line (5.9 keV, 4000cps). Mineralogical investigation was carried out through X-ray diffraction analysis(XRD), which is an effective tool to identify the mineralogical constituents. A Philips PW 1840 diffractometer with a Ni-filtered $\mathrm{Cu} \mathrm{K} \alpha$ radiation $(\lambda=1.54056 \AA)$. Diffraction patterns were recorded in a $4.005^{\circ}$ $59.775^{\circ} 2 \theta$ angular range with a $0.030^{\circ}-$ $0.05^{\circ}$ step in order to identify the physical properties of alabaster and the characteristics of its mineral constituents.

\section{Results and Discussions}

\subsection{Petrographical characteristics of studied alabaster}

The results obtained by polarizing microscopy showed that the alabaster includes three different types. Holocrystalline alabaster (massive alabaster), where the petrographic examination shows calcite spare crystals with sutured and concavo-convex contacts. The calcite spars also show blocky sparite fabric, with syntaxial overgrowth. A poikilitic texture is vepresevled. In some parts of the crystalline limestone, the grains are cemented in some parts by iron oxides. Banded or laminated alabaster, where the amorphous carbonate constitutes and the white bands exhibit a well marked colloform structure. Coarse elongated calcite crystals attain about 2$2.2 \mathrm{~mm}$, long and $0.5 \mathrm{~mm}$ thick, represent the studied banded alabaster. These crystals show rows of fibrous mosaic which is repeated throughout the rock. Finally, Cavernous alabaster, this type of alabaster is essentially a milky white, crystalline rock with abundant cavities. These cavities are filled in some parts by red to reddish soils. The unfilled voids are present between the progressive crystalline calcite. From specialized point of view, the petrographic examination of translucent alabaster of the Wadi ElAssuity shows calcite spare crystals with variety of bands consists of elongated fibrous crystals with the opaque milky white type. The petrographic examination of the Archaeological alabaster samples shows calcite grains with milky white grains which are very fine grained (micrite) to visible medium grains; it was observed destroyed calcite grains and micro crack in other crystals with halite crystal and hexagonal gypsum crystal with fine opaque iron oxide. The micro cracks, halite and gypsum crystals related to weathering processes, all of these features are shown in fig ${ }_{\mathrm{s}}(10-\mathrm{a}, \mathrm{b}, \mathrm{c}, \mathrm{d}, \mathrm{e})(11-\mathrm{a}, \mathrm{b}$, c) $(12-a, b)$ 


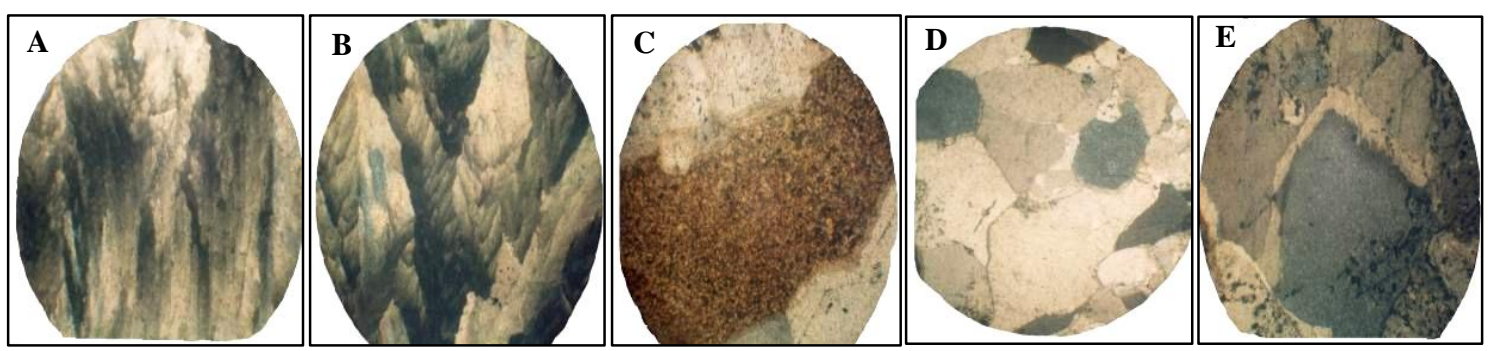

Figure 10 (a,b,c,d,e) petrographic view of massive alabaster at $\underline{\mathbf{a}}$ Wadi Sannur, $\underline{\mathbf{b}}$ Coarse elongated calcite crystals, $\underline{\mathbf{c}}$ cavernous alabaster $\underline{\mathbf{d}}$ the grains are cemented in some parts by iron oxides, $\underline{\mathbf{e}}$ crystals show rows of fibrous mosaic, (X40)
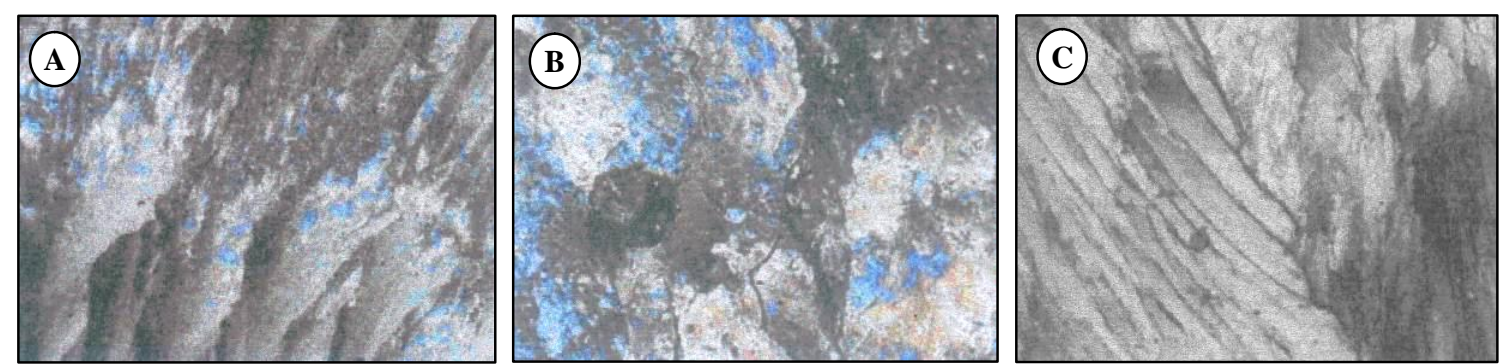

Figure $11(a, b, c)$ the petrographic view of translucent alabaster of the Wadi El-Asuity, (X40).
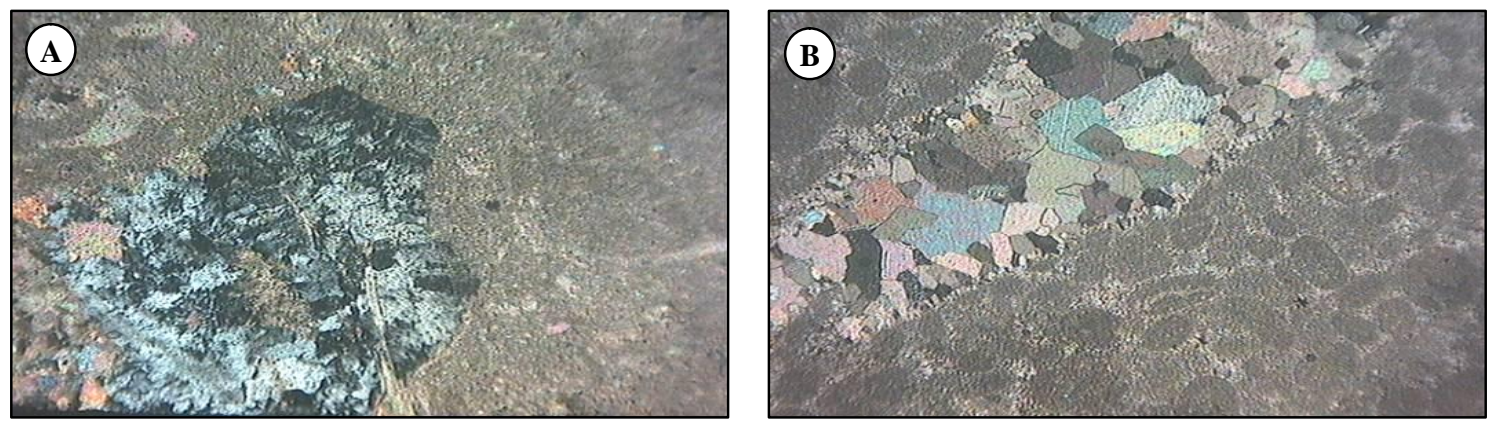

Figure $12(\mathrm{a}, \mathrm{b})$ the main minerals constituents of alabaster offering table on Karnack temples and Amon statue at Luxor temple (X40)

\subsection{X- ray fluorescence analysis}

$\mathrm{X}$-ray fluorescence detects higher calcium content in all samples and traces of $\mathrm{S}, \mathrm{K}, \mathrm{Fe}, \mathrm{Al}, \mathrm{Sr}$ and $\mathrm{Mg}$ contents in Wadi Sannur samples. The analysis detects higher silica and chloride content in archaeological samples and less content of calcium. The values are showed in tab. (1) \& figs. (13-a, b, c, d).

Table (1) elements of the minerals

\begin{tabular}{|l|c|c|c|c|}
\hline \multirow{2}{*}{ Element co. \% } & Amine S. & Ammonite S. & B & C \\
\hline $\mathrm{Ca}$ & 86.057 & 92.639 & 97.950 & 97.127 \\
\hline $\mathrm{Si}$ & 4.8923 & 3.2081 & 0.8526 & -------- \\
\hline $\mathrm{Cl}$ & 4.0151 & 0.5931 & ------- & -------- \\
\hline $\mathrm{K}$ & 1.8674 & 0.6594 & 0.6641 & -------- \\
\hline $\mathrm{S}$ & 1.0965 & -------- & -------- & -------- \\
\hline $\mathrm{Fe}$ & 0.6217 & 1.7341 & -------- & -------- \\
\hline $\mathrm{Mg}$ & -------- & ------- & ------- & 2.5341 \\
\hline $\mathrm{Al}$ & 1.4503 & 1.1662 & -------- & ------- \\
\hline $\mathrm{Sr}$ & -------- & -------- & 0.5333 & 0.3386 \\
\hline Total & $\mathbf{9 9 . 8 0 0 0}$ & $\mathbf{9 9 . 9 9 9 9}$ & $\mathbf{1 0 0 . 0 1 0}$ & $\mathbf{9 9 . 9 9 9 9}$ \\
\hline
\end{tabular}



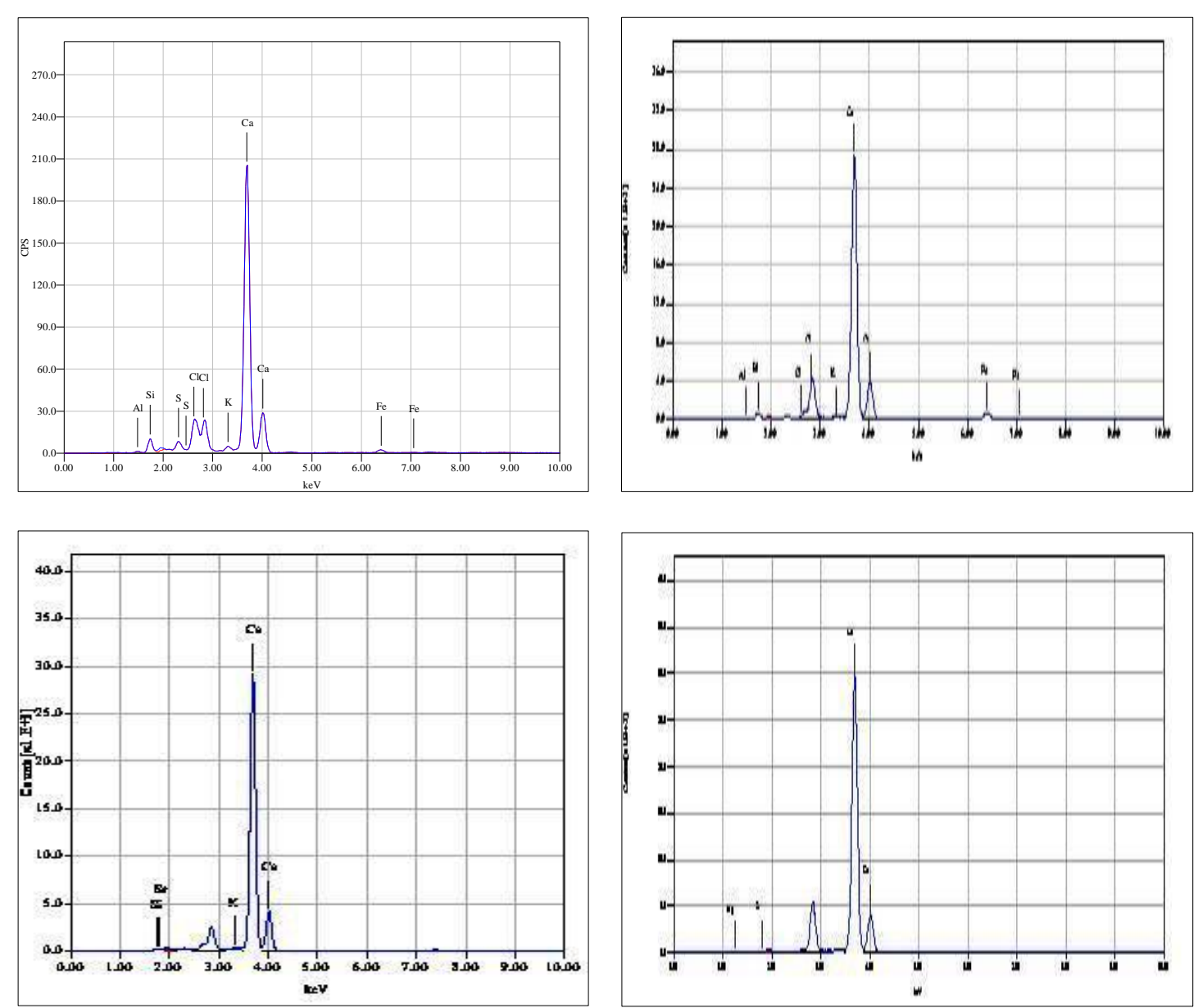

Figure 13 (a, b, c, d) the XRF pattern of $\underline{\mathbf{a}}$ Amone samples, $\underline{\mathbf{b}}$ Ammonite samples, $\underline{\mathbf{c}}$ Wadi Sannur samples, $\underline{\mathbf{d}}$ Wadi Assiuty samples

\subsection{Chemical composition of alabaster}

Chemical analysis of alabaster proved that the $\mathrm{CaO}$ content in both of wadi El Assiuty and Wadi Sannur is higher more than that of the Amine statue, the other elements of statue such as $\mathrm{SiO}_{2}, \mathrm{Cl}, \mathrm{SO}_{3}, \mathrm{Al}_{2} \mathrm{O}_{3}$ and $\mathrm{K}_{2} \mathrm{O}$ show higher concentrations than those of Wadi Sannur and Wadi El Assiuty. The concentration of $\mathrm{MgO}$ and $\mathrm{Fe}_{2} \mathrm{O}_{3}$ in the statue is less than those of Wadi El Assiuty and Wadi Sannur as listed in tab. (2). This difference may be related to the weathering processes occurring in the alabaster artifacts in the temples in Upper Egypt.

Table (2) chemical composition of different alabaster samples.

\begin{tabular}{|l|c|c|c|c|c|c|c|c|}
\multicolumn{1}{|c}{ Samples } & $\mathrm{CaO}$ & $\mathrm{SiO}_{2}$ & $\mathrm{Cl}$ & $\mathrm{SO}_{3}$ & $\mathrm{Al}_{2} \mathrm{O}_{3}$ & $\mathrm{~K}_{2} \mathrm{O}$ & $\mathbf{F e}_{2} \mathrm{O}_{3}$ & $\mathbf{M g O}$ \\
\hline Statue & 85.1 & 3.08 & 2.81 & 1.95 & 1.68 & 1.63 & 0.68 & 1.04 \\
\hline Wadi Sanurr & 97.8 & 0.05 & 0.89 & 0.08 & 0.57 & 0.72 & 0.9 & 1.9 \\
\hline Wadi Asuti & 94.06 & 2.07 & 1.12 & 0.9 & 1.12 & 0.09 & 1.17 & 1.67 \\
\hline
\end{tabular}

\subsection{X-Ray Diffraction (XRD) investigation}

The results obtained by XRD analyses showed that all samples consist of calcite $\mathrm{CaCO}_{3}$ as main mineral component with a smaller quantity of Quartz $\mathrm{SiO}_{2}$, Iron Silicate
$\mathrm{FeSiO}_{2}$ and Kaolinite. Archaeological alabaster samples shows less ratio of Halite $\mathrm{NaCl}$ and Gypsum, fig.14 (a, b, c, d, e, f) 

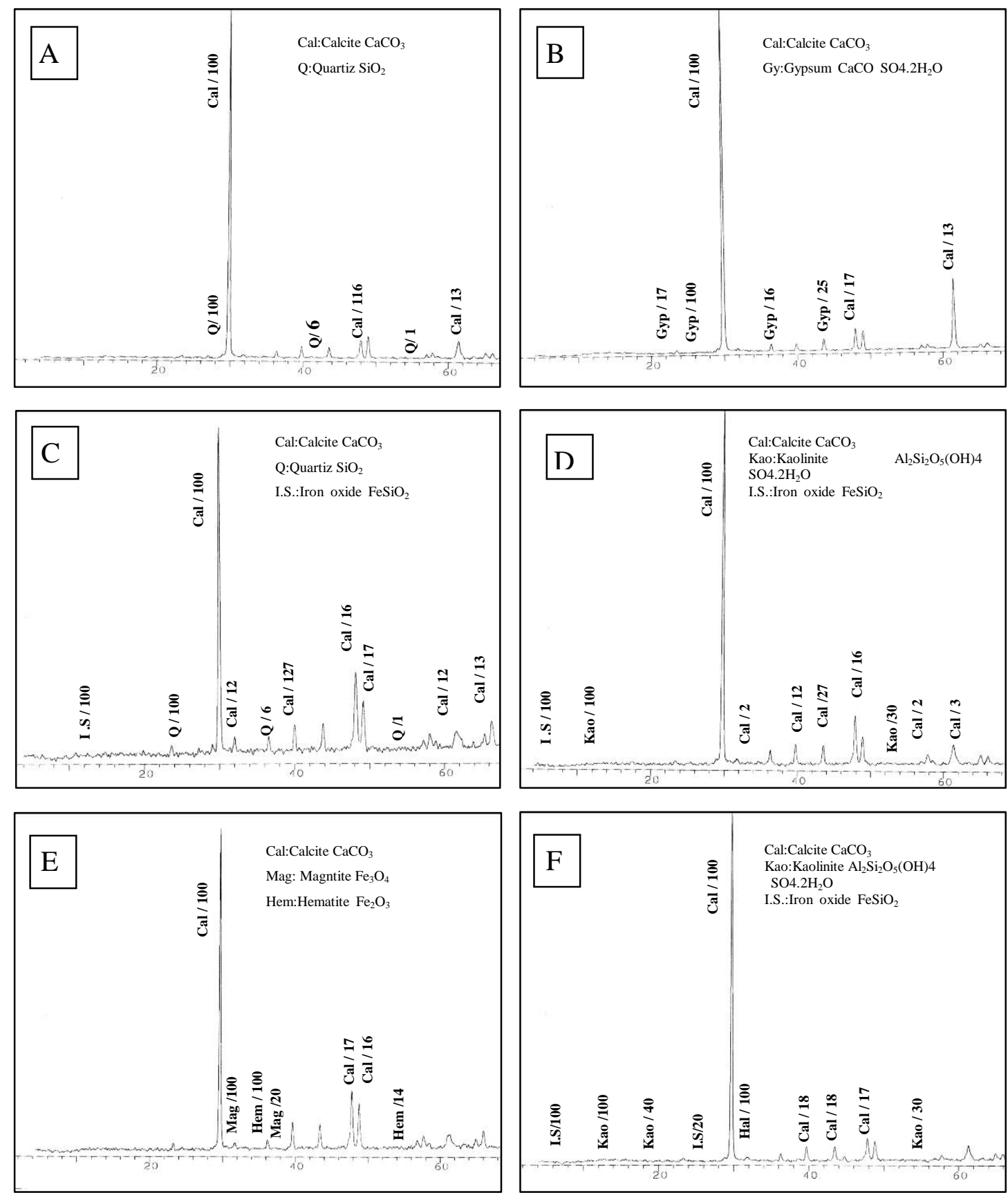

Figure $14(\mathrm{a}, \mathrm{b}, \mathrm{c}, \mathrm{e}, \mathrm{f}) \mathrm{XRD}$ pattern of alabaster samples, alabaster consists of calcite $\left(\mathrm{CaCO}_{3}\right)$ as a major minerals.

\subsection{Scanning electron microscope study}

The study carried out through SEM allows us to confirm the result already obtained through other analysis. It reveled that the main mineral constituent of studied alabaster are calcite grains with cubic and longitude form, fig. $15(\mathrm{a}, \mathrm{b})$, cemented in some parts by iron oxides. The clay minerals and Gypsum are also exiting among the calcite grains, fig. 16 (a, b, c). Scanning study also indicated sodium chloride in to phases of crystallization, they are cubic form, fig. $17(\mathrm{a}, \mathrm{b})$ and prisms one like crystals, fig. 18 (a, b). SEM shows the disintegration of Calcite grains and has different weathering noted as grain surface damage and micro-exfoliation due to the effect of soluble salts. Also, it showed the content of gypsum in the samples is due to the transformation of calcite into gypsum. 

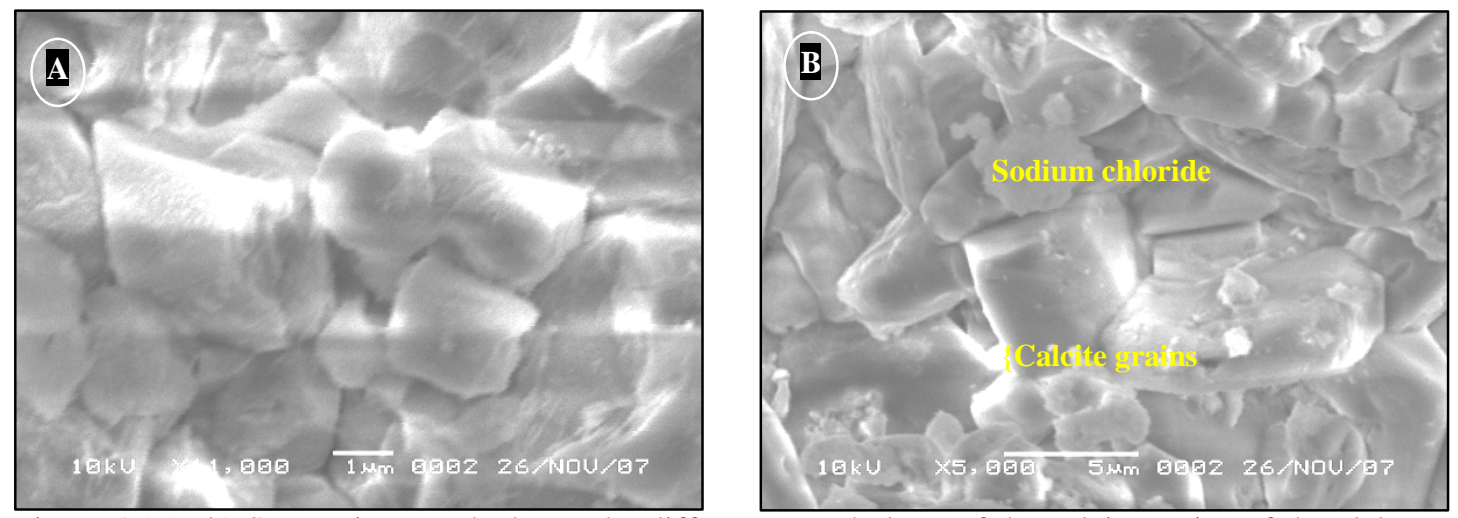

Figure $15(a, b)$ SEM micrograph shows the different morphology of the calcite grains of the alabaster stone.
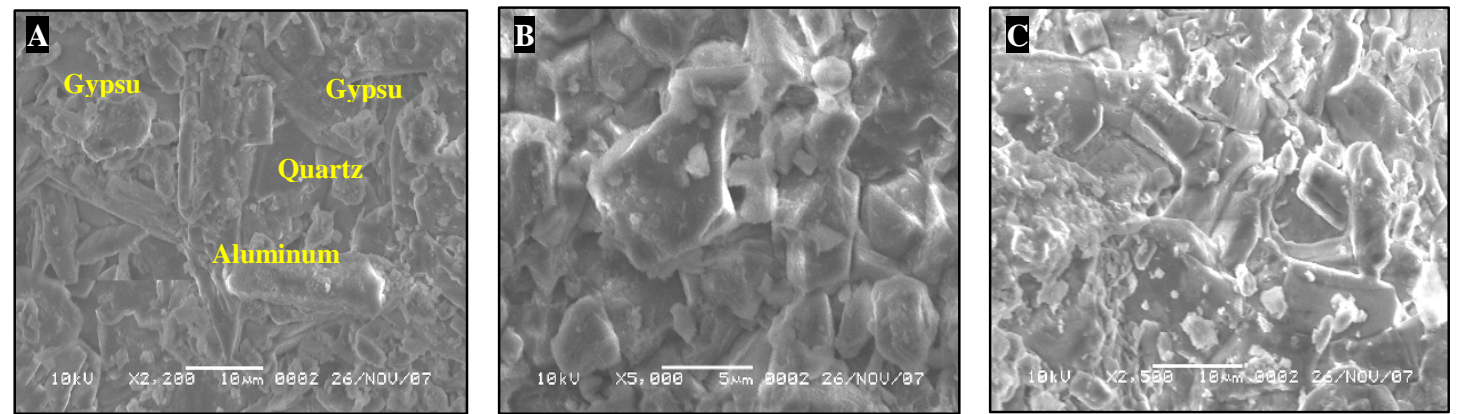

Figure $16(\mathrm{a}, \mathrm{b}, \mathrm{c})$ SEM micrograph shows $\underline{\mathbf{a}}$ clay minerals, prismatic crystals of halite and gypsum, $\underline{\mathbf{b}}$ sodium chloride in cubic form between grains of calcite from statue of Amen in Luxor temple, $\underline{\mathbf{c}}$ destroyed of calcite grains from the Thutmose IV offering table in the Karnak temple
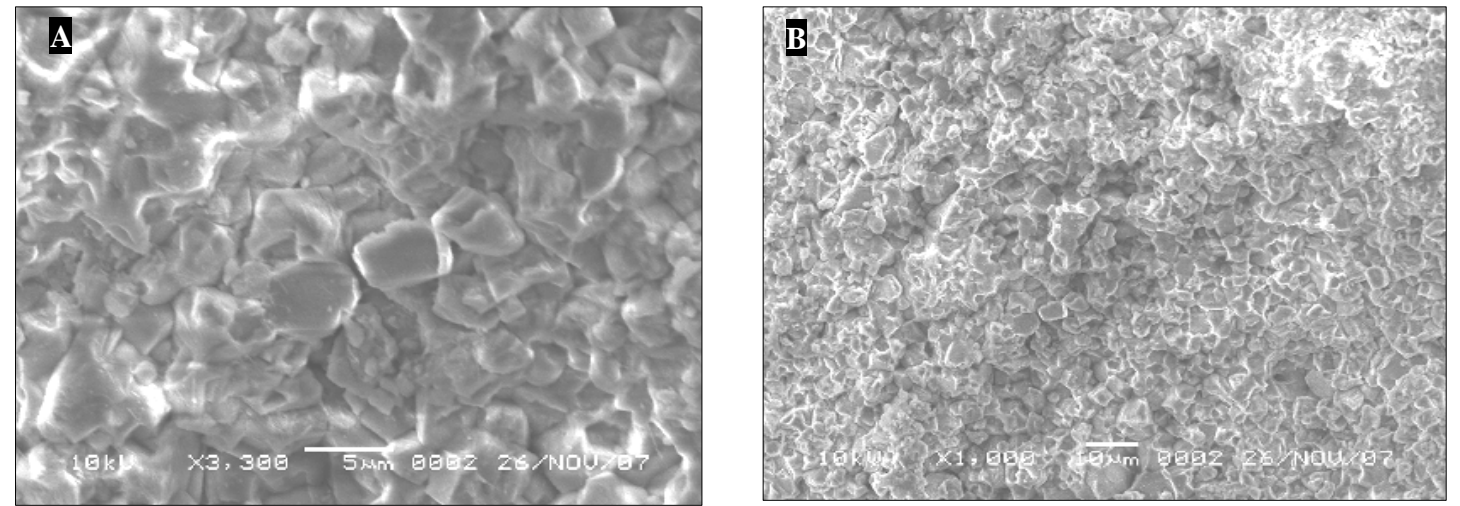

Figure 17 (a, b) SEM micrograph shows the mineralogical component of alabaster at Wadi Sannur.
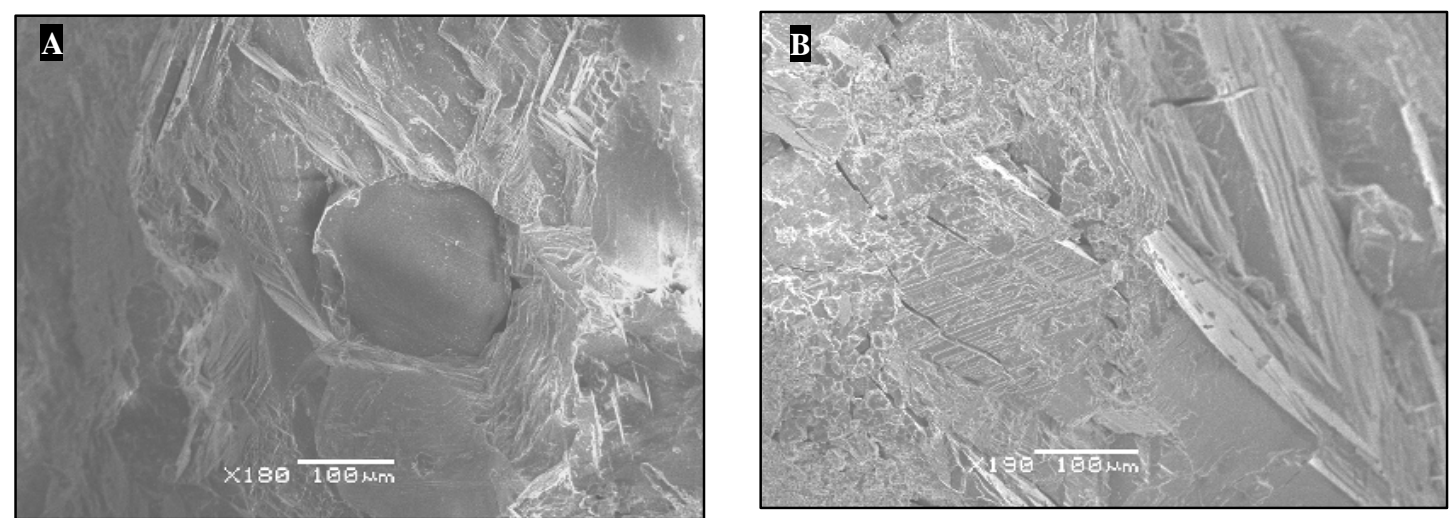

Figure 18 (a, b) SEM micrograph shows the mineralogical component of alabaster at Wadi El-Assuity. 


\section{Evaluation of the consolidants materials for alabaster}

The field study and lab analysis show that the natural weathering of Alabaster in South Egypt is inevitable. The use of chemical "preservatives" to stabilize stone deterioration has been largely unsuccessful, especially when application has been based on the concept of providing a protective film. A more promising area of study has been the experimental application of consolidants. It has been suggested that "the most important function of a stone consolidant is to reestablish cohesion of the particles of deteriorated stone. Restoration of integrity is achieved by deposition of a new, durable binding material within the pore system, a process that should significantly improve measurable physical properties. The aim of a preservative is to totally preserve the stone in whatever state of weathering it has reached and stop all future decay; Consolidation on the other hand should aim to stabilize the friable stone whilst still allowing weathering to take place as a result of natural processes and at a natural rate. The ideal polymer for use in stone consolidation would be one that can reverse the degradation of a stone, returning it as nearly as possible to its original condition. For the treatment of the inhomogeneous porous stone materials like alabaster, the risk of open porous system and cracks in a material should be considered. The water repellent normally works well if there are no cracks $(>0.3 \mathrm{~mm})$ or other defects in the material, which may allow water to penetrate, resulting in significant moisture [20]. The study was aimed to evaluate the efficiency of the various hydrophobic products in laboratory in order to recommend the protective treatment for the conservative treatment of the alabaster. To evaluate potential suitability of the products for the consolidation of deteriorated alabaster, alabaster samples were chosen. To ensure statistical reliability of test data, our experimental work used un-weathered samples. For the evaluation of consolidant application in a specific situation, Wadi Sannur alabaster was chosen for the initial series of tests because the lab analysis showed a big resemble between the Wadi Sannur alabaster and the alabaster used in Karnack and Luxor temples. The alabaster cubes $(4 \times 4 \times 4 \mathrm{~cm})$ taken from the quarry of Wadi Sannur, fig.(19). The number of samples, their dimension and tests carried out on them are listed as follows:

(a) 6 samples for water absorption and porosity.

(b) 6 samples of $4 \times 4 \times 4 \mathrm{~cm}$ for compressive strength,

(c) 24 samples of $4 \times 4 \times 4 \mathrm{~cm}$ for ageing

(d) 24 samples for consolidation by 4 resins after artificial ageing.

Our program of laboratory testing based primarily on measurements of physical and mechanical properties of fresh alabaster. Evaluation of these characteristics was made without exposure to a natural or artificial weathering environment and must be interpreted as defining only the initial improvements possible with a consolidation treatment, tab. (3).

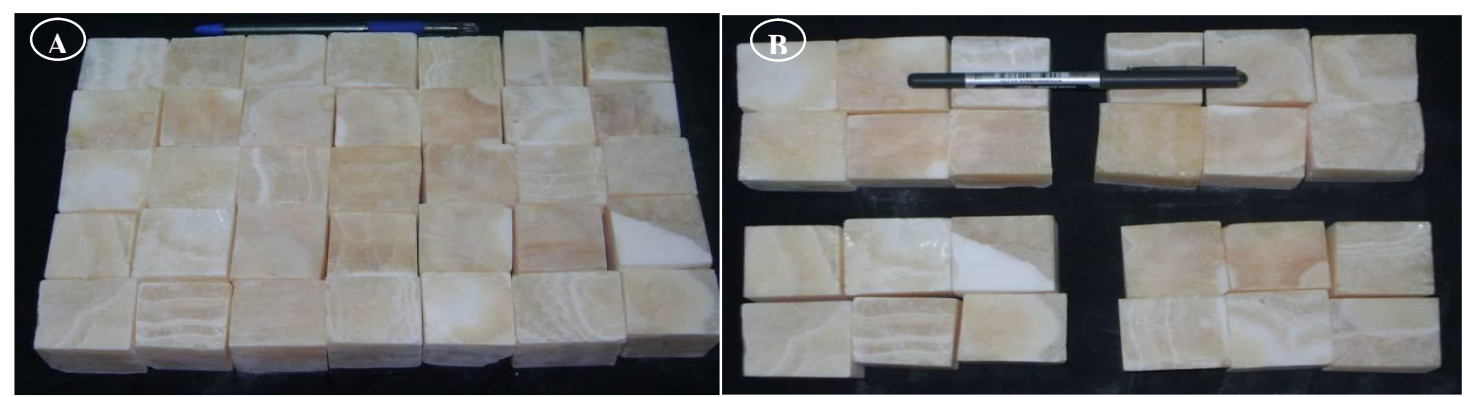

Figure (19) the alabaster samples before any treatment or artificial weathering. 
Table (3) the main physico-mechanical characteristics of studied alabaster.

\begin{tabular}{|l|l|l|}
\multicolumn{1}{c|}{ Property } & \multicolumn{1}{c}{$\begin{array}{c}\text { Wadi Sannur } \\
\text { samples }\end{array}$} & $\begin{array}{c}\text { Wadi Assiuty } \\
\text { Samples }\end{array}$ \\
\hline Bulk Density $\left[\mathrm{gm} / \mathrm{cm}^{3}\right]$ & 2.18 & 1.98 \\
\hline Water absorption $[\%]$ & 2,24 & 3.38 \\
\hline Porosity[\%] & 3,52 & 4.69 \\
\hline Compressive strength $\left[\mathrm{kgm} / \mathrm{cm}^{2}\right]$ & 212 & 206
\end{tabular}

Physio-mechanical examination carried out on the alabaster samples showed Wadi Sannur alabaster has a mechanical strength and has also low porosity in comparison with the Wadi Assuity alabaster which has rather poor clay and ferruginous cementing materials. To investigate the durability of the alabaster against the aggressive environmental condition wet-dry cycles was applied as follows:14 hours total immersion in water, 2 hour in room temperature, 8hours in an oven at $105{ }^{\circ} \mathrm{C}$. Salt weathering, simulation soundness tests were carried out. Rock samples exposure to higher salt concentrations (using 14\% sodium chloride solution which is considered as one of the most aggressive soluble salts according to (ASTM 1990). 20 cycles composed as follows: 2 hours of immersion in solution of $\mathrm{NaCl}$, 2hours of draining in the room condition, 20hours of drying at $105{ }^{\circ} \mathrm{C}$. The aged samples were washed in a running tap water. There was perceivable change in the appearance of samples were held at each temperature. A slight fading was noticeable after exposure to $105^{\circ} \mathrm{C}$ heat in the $12^{\text {th }}$ cycles, as shown in fig. 20 (a, $b, c)$. There was a substantial decrease in physical and mechanical properties as shown in tab. (4).

Table (4) the main physio-mechanical characteristics of studied alabaster after artificial weathering.

\begin{tabular}{|l|l|l|}
\multicolumn{1}{c}{ Property } & \multicolumn{1}{c}{$\begin{array}{c}\text { After heating ageing } \\
\text { cycles }\end{array}$} & \multicolumn{2}{c}{ After soundness by } \\
BaCl
\end{tabular}
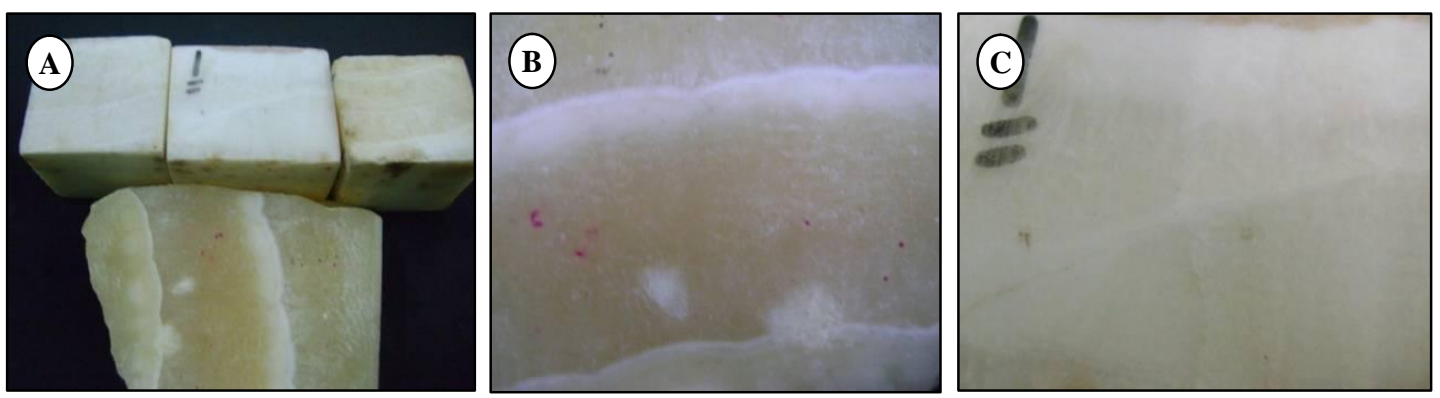

Figure (20) alabaster samples after heating ageing cycles.

To establish the influence of the consolidants, parallel study was carried out on aged and consolidated alabaster samples. For this study, four products of conservation co-polymers based on silicone and acrylic were tested tab. (5). The water repellent silicone treatment aims to eliminate or reduce capillary absorption of water in driving rain, prevent wet absorption of reactive gases, reduce damage effects from frost, diminish biological growth and the amount of particulate fixation preventing the soiling [21].Alabaster samples were cleaned, wetted and left in the air until the water content was $0.2 \mathrm{gm}$. This procedure favors the polymerization of organosilicon 
products (Rosario\&Others1996) [22]. In an attempt to simulate field application of the consolidant, laboratory application was met by three separate two minute immersions at 1520 minute intervals. The same treatment was repeated after 24 hours. After 21 days at indoor curing at room temperature. Visual inspection was used to evaluate alteration of surface appearance (color and gloss). According to the visual appearance of the treatment, the best products are Rhodorsil 224 and Wacker L290+B66, for the Acryloid B-82 changes are quite slight and did not modify the total appearance of the treated stone. The Wacker $\mathrm{OH}+\mathrm{B} 72$ change the color of the alabaster significantly to an unacceptable level. The performance of the physical properties and changes in porosity of the consolidant materials applied on the alabaster samples is shown in fig. (21).

Table (5) type of tested Conservation co-polymers based on silicone and acrylic

Consolidant

Paraloid (B72) + Wacker-silicone-OH

Paraloid (B66) + Wacker-silicone 290L

(S) Rhodorsil 224

Paraloid (B82)

\section{Description}

Non hydrophobic product containing tetraethoxysilane and oligomers, ketonic solvent and organometaallic compound as catalyst $+5 \%$ Acryloid B72 in trichloroethylene

(polyslioxane resin) diluted in turpentine $20 \%+$ 5\% Acryloid B66 diluted in trichloroethylene

(alkyl-alkoxyl-siloxane) diluted in trichloroethylene.

Acryloid B-82 dissolved in toluene 5\% (an isobutyl methacrylate polymer. It is an alkydcompatible acrylic ester).

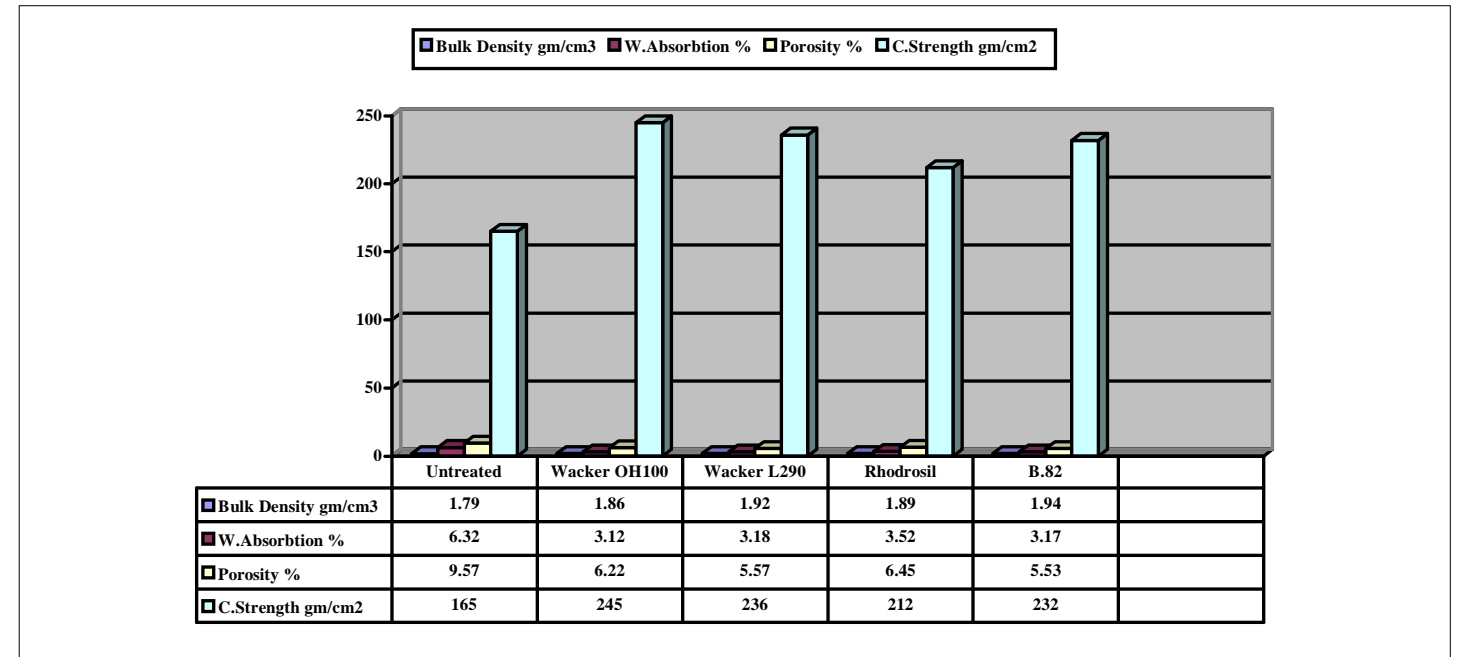

Figure (21) physical and mechanical properties of consolidant materials applied on Alabaster

The sodium Rhodorsil 224 has diminished the water absorption practically to minimum: from the $6.32 \%$ for untreated stone to $3.52 \%$ for the treated, it improved the bulk density from 1.79 in untreated sample to 1.86 for the treated and the compressive strength increase from $165 \mathrm{~kg} / \mathrm{cm}^{2}$ for untreated samples to $212165 \mathrm{~kg} / \mathrm{cm}^{2}$ to treated samples. The Wacker L290 + B66has the lowest diminish of water absorption (3.18\%). It improved the compressive strength from $165 \mathrm{~kg} / \mathrm{cm}^{2}$ for untreated samples to $236 \mathrm{~kg} / \mathrm{cm}^{2}$ to treated samples. silicon compound Wacker $\mathrm{OH}+\mathrm{B} 72$ have very close properties in all the tests characterized by the good absorption diminish about 
$3.12 \%$ for water absorption and gave the high degree of compressive strength $245 \mathrm{~kg} / \mathrm{cm}^{2}$. The Acryloid B-82 has the most effective diminish of the water absorption (3.17\%). According to the obtained data from the evaluation of the efficiency of the compressive strength of the products laboratory, it could be concluded that: all consolidant treatment improved the compressive strength of all samples. The consolidant samples were subjected to 20 wettingdrying and sodium chloride ageing cycles. The same pervious properties were measured. Samples of alabaster endured all 20 wetting-drying cycles without heavier damage but some deposits started to form on the surface. There was no perceivable change in the appearance of samples treated with silicone-based, remarkable change arose in the Acryloid B.82 which employed changed the alabaster-color turned darker, local glossy areas appeared on the stone surface after ageing cycles as shown in fig. $22(a, b)$.

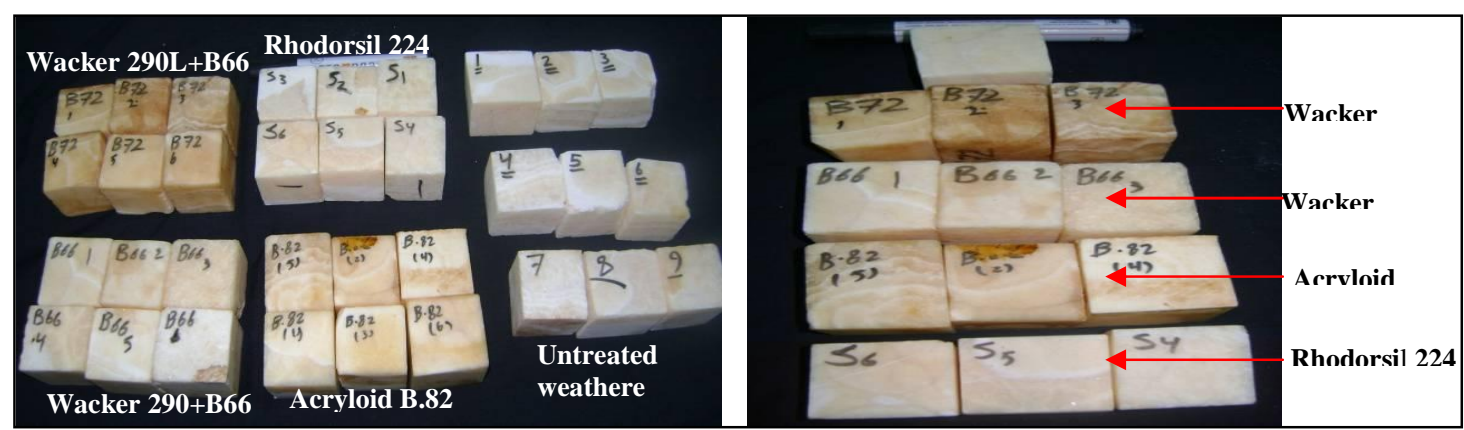

Figure $28(a, b)$ alabaster samples after treated with consolidants .

As expected, the percent water absorption was significantly diminished by treatment with the Rhodorsil 224 consolidant, but not for those treated with the B 72. Reduction of porosity was small with both treatments, indicating the retention of a relatively open pore structure. There was a substantial increase in compressive strength in samples treated with the B 72, B 66, and B 82 consolidants, fig. (23).

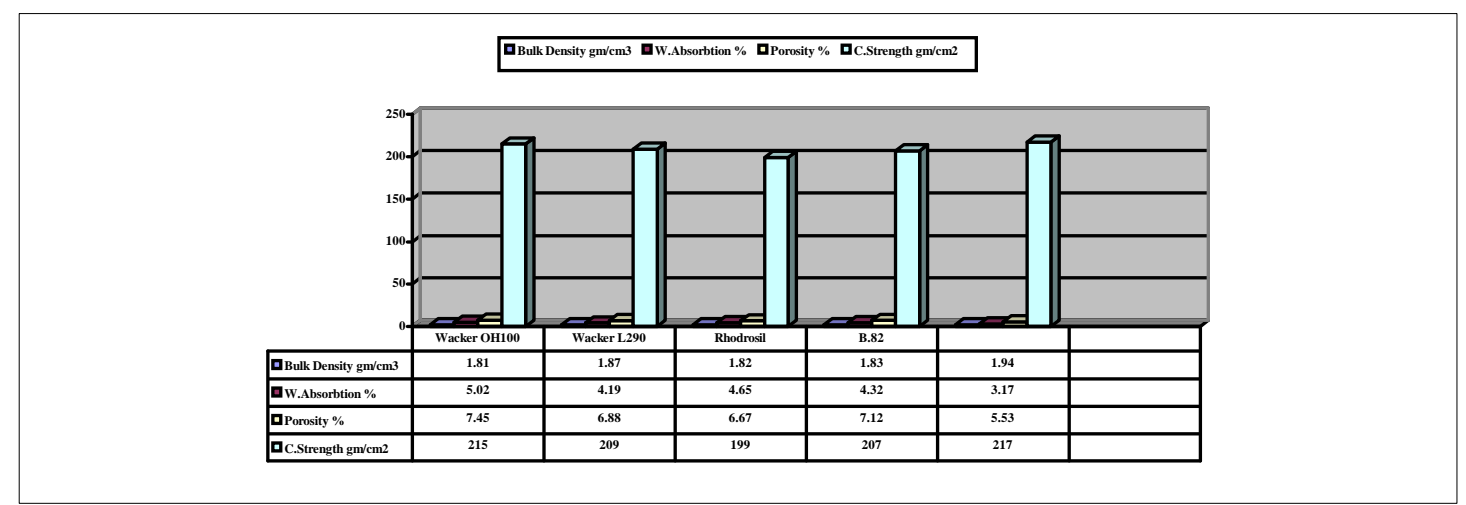

Figure (23) physical and mechanical properties of consolidant materials after weathering cycles

SEM study, after completion of the experimental program, there was an opportunity to further study the treatment through SEM photographs. This investigation aimed at establishing the location of the penetrated consolidants. The appearance of the consolidant at high magnifications (500x and higher) as it was to be expected, the consolidants were deposited in the pores and in less dense sections of the contact zone. The consolidant were found to be present on the surface of the alabaster grains and on the other structure units neighboring the pores, as well as in the contact zone. Only in the case of the Wacker-silicone 
$290 \mathrm{~L}$ is there variation in the initial aspects of the samples after the treatment.. Where the mineral grains seem clearer after covered them, one may also note a rigid layer being formed, covering grains sometimes and joining them on others. Wacker $\mathrm{OH}+\mathrm{B} 72$ show some micro-cracking after ageing, all of the morphological features of the investigated samples are as shown in fig. $(24,25,26,27)$.
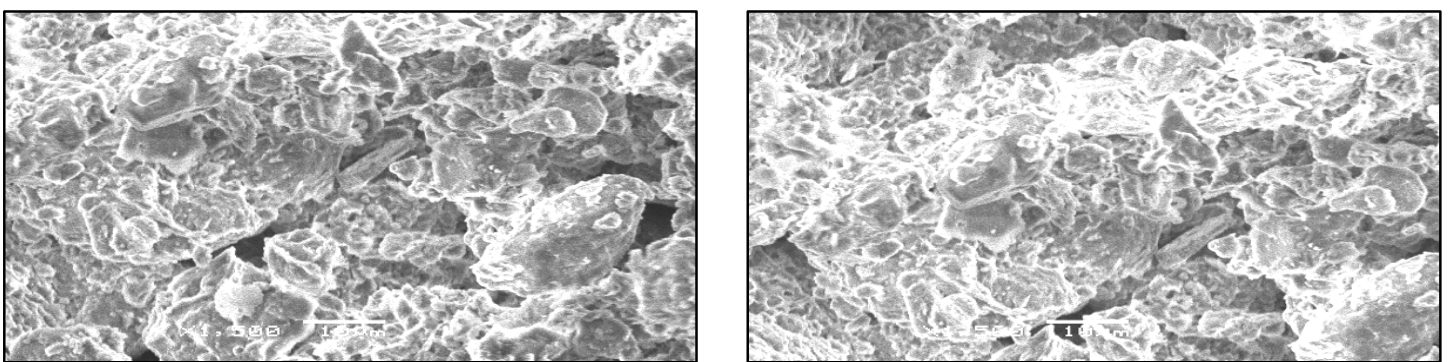

Figure (24) SEM micrographs of alabaster samples treated with Rhodorsil. 224
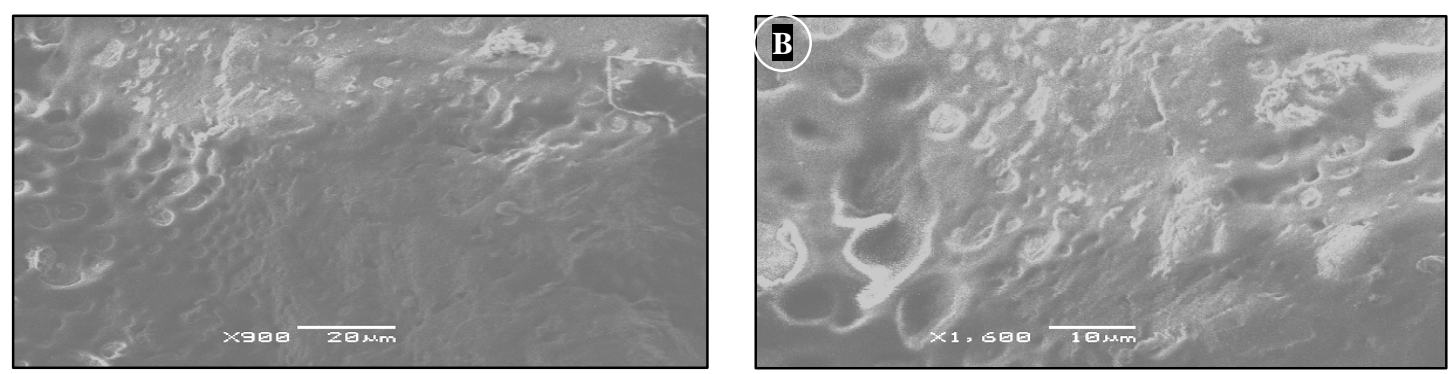

Figure (25) SEM micrographs of alabaster samples treated with Wacker-silicone 290L.
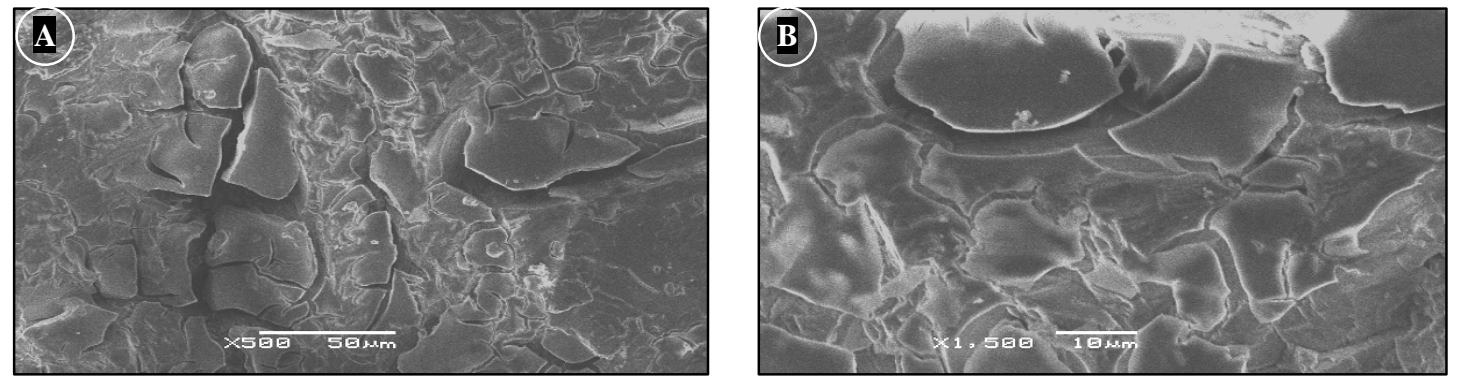

Figure (26) SEM micrographs of alabaster samples treated with Wacker $\mathbf{O H + B 7 2}$
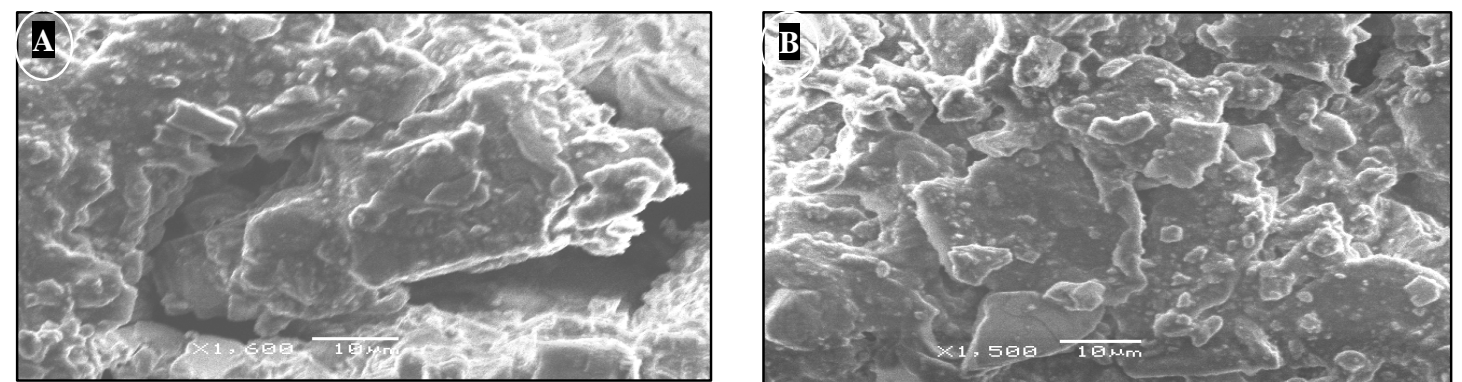

Figure (27) SEM micrograph of treated Alabaster sample with Paraloid B.82

\section{Conclusion}

Alabaster is an ornamental stone that was widely used in ancient Egypt and it had a lot of deterioration factors. The weathering of alabaster appears to be rather different from the weathering of other stone materials because of its chemical composition and its high porous texture. The laboratory evaluation of the silicone and acrylic treatment on alabaster samples showed that the Rhodorsil 224 resins gave satisfied results, because they deeply penetrated into the stone and consolidated its inner structure and showed good results of effective diminish of water absorption, decrease of total absorption. The experimental results indicated 
that the treatment of the deteriorated alabaster stone monuments by Whacker $290 \mathrm{~L}$ followed by Acryloid B66 products dissolved in trichloroethylene increase the strength of alabaster stone and protect it against the attack of moisture. Also the results illustrated that the Acryloid B72 and Acryloid B82 employed changed the alabaster-color turned darker, local glossy areas appeared on the stone surface after ageing cycles.

\section{References}

[1] Harrell, J., (1990). Misuse of the term 'alabaster' in Egyptology, Gottinger Miszellen, Vol. 119 pp: 37-42

[2] Harrell, J., (1995). Ancient Egyptian origins of some common rock names, Journal of Geological Education, Vol. 43 (1) pp: 4-30

[3] Harrell, J., Broekmans, A. \& Smith, D., (2007). The origin, destruction and restoration of color in Egyptian Travertine, Archaeometry, Vol. 49 (3), pp: 421-436.

[4] Kittchen, K., (1973). The third intermediate period in Egypt, Warminster: Aris \& Phillips.

[5] Aston, B., Harrell, J. \& Shaw, I., (2000). Stones, in: Nicholson, P. and Shaw, I. (Eds.), ancient Egyptian materials and technology, Cambridge University Press, Cambridge, pp: 5-77

[6] Lucas, A., (1962). Ancient Egyptian materials and industries, revised by Harris J.R, Edward Arnold, London.

[7] Harrell, J., (2001). Calcite, in: Redford, D. (Ed.) the Oxford encyclopedia of ancient Egypt, Vol. 1, Oxford University Press, London

[8] Zaki, R., (1988). Petrological and geochemical studies of some Alabaster rocks in Egypt, M. Sc., Faculty of Science, Minia Univ., Egypt.

[9] El Naggar, M., (1962). Petrological studies on the Egyptian Alabaster, Ph.D., Faculty of Science, Assiut Univ., Egypt.

[10] Dabous, A. \& Osmond, J., (2000). The isotopic study of speleothems from the Wadi Sannur cavern, Eastern Desert of Egypt, Carbonates and Evaporates, 15 (1), pp:1-6.

[11] Said, R., (1990). Cenozoic, in: Said R., (Ed), the geology of Egypt, Balkema, Rotterdam A., pp: 86-451.

[12] Tourre, S., (2000). Cave-filling herringbone calcite-morphology and

geochemistry of an unusual carbonate cement from Egypt, M.Sc., University of California at Davis, USA.

[13] Halliday, W. (2003). The world's largest gour-Wadi Sannur cavern, Egypt, NSS News, Vol. 61 (1), pp:46.

[14] Adams, J., Palmer, F. \& Staley, J., (1992). Rock weathering in deserts: mobilization and concentration of ferric iron by microorganisms, Geomicrobiology, Vol. 10 (2), pp: 99-114.

[15] Rafael, F., Concepcion M. \& Fransisco M., (2000). Petrophysical analysis of the sculptures decay at the cathedral of Burgos, Spain. In V. Fassina (Ed.) $9^{\text {th }}$ International congress on deterioration and conservation of stone, Vol. 1, Elsevier, pp:125-134

[16] El-Gohary, M., (2010). Investigation on limestone weathering of El-Tuba minaret EL Mehalla, Egypt: A Case Study, MAA, Vol. 10 (1), pp: 61-79

[17] Siegesmund, S., Weiss T. \& Tschegg E., (2000). Control of marble weathering by thermal expansion and rock fabrics. In V. Fassina (Ed.) $9^{\text {th }}$ International congress on deterioration and conservation of stone, Vol. 1, Elsevier, pp: 213-215

[18] Urzi, C., Lisi, S., Criseo, G. \& Pernice, A., (1991). Adhesion and degradation of marble by a micrococcus strain isolated from it. Geomicrobiology, Vol. 9 (2-3) pp: 81-90

[19] Drever, J. \& Stillings, L., (1997). The role of organic acids in mineral weathering, Colloids and Surfaces A: physicochemical and engineering aspects, Vol 120 (1-3), 167-181 
[20] Sandin, K., (1999). Influence of cracks on moisture conditions in facades with water-repellent treatments, Internationale Zeitschrift für Bauinstandsetzen und Baudenkmalpflege Vol. 5 (5), pp: 499-521

[21] Ashurst J. \& Ashurst, N. (1990). Practical building conservation, Vol.1., Stone masonry, Gower
Technical Press, English Heritage, London

[22] Rosario, V., Lourdes, M., Jose, V., Angel, B. \& Manuel, A., (1996). Characterization and conservation of the stone used in the Cathedral of Almera (Spain), In: Riederer, J. (ed.) $8^{\text {th }}$ International congress on deterioration and conservation of stone, Vol..2, , Berlin, pp:89--98 